Article

\title{
Ammonium Cycling and Nitrification Stimulation during Oil Sludge Remediation by Gram-Positive Bacteria Lysinibacillus sphaericus Using Red Wiggler Earthworm Eisenia fetida
}

\author{
Juan Diego Acevedo ${ }^{1}$ and Jenny Dussán ${ }^{1, * \mathbb{D}}$ \\ Centro de Investigaciones Microbiológicas-CIMIC, Departamento de Ciencias Biológicas, \\ Universidad de los Andes, Carrera 1 No. 18A-10 J-206, Bogotá PC 111711, Colombia; \\ jd.acevedo245@uniandes.edu.co \\ * Correspondence: jdussan@uniandes.edu.co; Tel.: +57-1-3394999 (ext. 3644)
}

Received: 5 October 2020; Accepted: 3 November 2020; Published: 13 November 2020

check for updates

\begin{abstract}
The performance of a mixture between L. sphaericus and E. fetida was evaluated for ammonium cycling and nitrifying bacteria stimulation during oil sludge remediation. The addition of E. fetida significantly increased ammonium concentration $(p=0.0218)$ and total Colony-forming units (CFU) count $p=0.02848)$. However, oil sludge with worms and L. sphaericus reached lower ammonium concentrations and CFU counts than sludge with worms alone. Sludge inoculated only with L. sphaericus presented higher ammonium concentration than sludge without inoculum, but the bacterial population reached a lower density during the final days. Final DNA and RNA extractions from all treatments amplified for L. sphaericus putative amoA and Gram-negative nitrifying bacteria amoA genes correlated with diminished ammonium concentrations during the final days of the experiment. Final RNA extractions for L. sphaericus amplified for Molybdenum transporter gene suggesting possible nitrogen fixation by L. sphaericus. The addition of Red Wiggler Earthworm to oil sludge remediation systems may provide better conditions for bacterial populations to carry out hydrocarbon degradation. The addition of E. fetida to a L. sphaericus crude oil biodegradation system may improve soil ammonium concentrations and nitrifying activity, and this could be crucial in oil sludge remediation because of bacterial inhibition due to high $\mathrm{C}: \mathrm{N}$ ratios. The final product of this process may be used for soil enhancement due to its richness in nutrients and beneficial bacterial populations.
\end{abstract}

Keywords: Lysinibacillus sphaericus; Eisenia fetida; bioremediation; crude oil sludge; ammonium; nitrification; amoA; molybdenum transporter

\section{Introduction}

Crude oil extraction, transportation and refinement produces residual sludge composed by hydrocarbons, paraffin, produced water, sediments, and other possible contaminants such as heavy metals, sulfuric compounds and chemicals added during the operation [1]. The complexity of this mixture makes it very difficult and expensive to remediate, making crude oil sludge a persistent contaminant. Bioprospecting microbial communities found in this kind of sludge led to the discovery of different bacterial consortiums with the ability to break apart these compounds into less toxic molecules. Based on these findings, different crude oil bioremediation techniques have been developed resulting in a system that is cheaper, more efficient, and more sustainable compared to other remediation practices such as chemical degradation or incineration $[2,3]$. 
Previous bioprospecting of native Colombian bacteria for crude oil degradation has led to the current use of different strains of Lysinibacillus sphaericus in remediation processes for oil companies around the country [4]. The strains used in these treatments are non-pathogenic and present high degradation rates for different oil hydrocarbons achieving significant results in the environmental recovery of contaminated soils, with removal efficiencies up to $95 \%$ for $\mathrm{C} 10$ to C28 hydrocarbons in diesel oil assays and up to $84.1 \%$ and $60.1 \%$ for oil sludge in open air and closed arrays, respectively [5]. L. sphaericus is also involved in nutrient cycling. Genomic annotation has revealed the presence of several genes involved in the nitrogen cycle including Molybdenum transport system permease protein encoding gene (modB) needed to assemble Nif enzyme, nifU involved in the formation of Fe-S clusters for nitrogen fixation, Ammonium transporter and putative ammonia monooxygenase responsible for the first step in nitrification [6]. These abilities have also been proven by ammonium and nitrite quantification during in-vivo studies focused on nitrogen cycling $[7,8]$.

Microbial remediation of crude oil sludge may be enhanced using earthworms $[9,10]$. Several studies have proven that adding Red Wiggler Worm Eisenia fetida to contaminated soils improves degradation rates of both, heavy [11] and light hydrocarbons [12]. Red Wiggler Worms also have the capacity to improve nutrient cycling significantly, raising ammonium and nitrite concentrations in soil [13] and bacterial populations related with nutrient cycling [14]. These abilities have been verified by gut bacterial genomic annotations that show abundance in genes related to aromatic hydrocarbon degradation, dehalogenation, nitrogen fixation, and ammonium oxidation [15]. E. fetida is commonly used in composting processes given its high degree of adaptability, resistance, and high reproductive rates, as well as its vast commercial availability worldwide [16]. Also, it has been widely used in remediation studies showing promising results for soil structure improvement, promotion of microbial numbers and hydrocarbon degraders and increased microbial respiration resulting in total petroleum hydrocarbons (TPH's) degradation [17].

Several studies propose that nitrification is dominated by archaea or beta and gamma proteobacteria commonly classified as AOA (ammonia oxidizing archaea) and AOB (ammonia oxidizing bacteria). In the first stage of nitrification, ammonium is reduced to hydroxylamine by the ammonia monooxygenase enzyme (AMO), in $\mathrm{AOB}$ this enzyme is encoded by the genomic amoCAB operon $[18,19]$. The amoA gene of this operon is highly conserved, and thus, very useful for environmental studies in which nitrifying activity is evaluated [19]. Some Gram-positive bacteria have genes homologous to amoCAB, as is the case for L. sphaericus, where a putative amoA gene is present [6]. These findings suggest that bacteria other than beta and gamma proteobacteria may be involved in nitrification processes with significant effects on ammonia oxidation rates and nitrite concentrations in soil [20].

Ammonia monooxygenase is also capable of degrading hydrocarbons via cometabolism, whereby electrons produced by ammonium oxidation are reused by AMO for hydrocarbon oxidation. Due to its wide range of substrates, this enzyme is capable of degrading alkenes, alkanes, and halogenated and aromatic hydrocarbons. Cometabolism of hydrocarbons by AMO is a complex phenomenon that generally causes AMO activity inhibition, and hydrocarbon byproducts may affect cell physiology [21-23]. Cometabolism has been proved to be an important process in the degradation of xenobiotic hydrocarbons [24].

The objective of this study is to determinate ammonium cycling and nitrification stimulation during the biodegradation of petroleum hydrocarbons by L. sphaericus using E. fetida by monitoring bacterial populations, ammonium concentrations, and the expression of amoA and modB.

\section{Materials and Methods}

\subsection{Summary}

This experiment was divided into two stages: Pretreatment and Treatment. During the Pretreatment the biological degradation was initiated at high crude oil concentrations and monitored by performing 
ammonium determinations, once ammonimun concentrations begun to raise the pretreatments were dilluted to permisibile TPH's levels in order to inititate the Treatment, during this stage the treatments were monitored for ammonimum concentration, vegetative cell count, and amoA and ModB gene presence and expression. A brief summary of the methodology is presented in Figure 1.

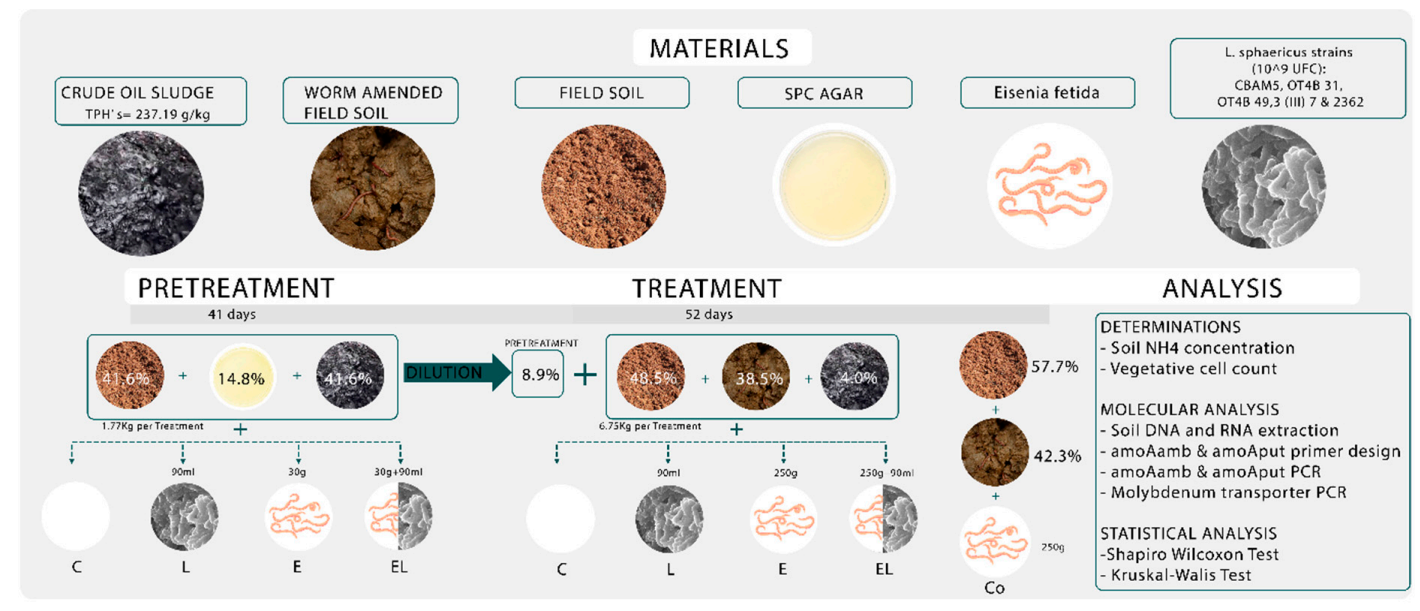

Figure 1. Methodology summary.

\subsection{Materials}

Heavy crude oil sludge and unpolluted soil samples were obtained from Biointech, a Colombian company dedicated to soil and water treatment for environmental recovery. The samples were collected at Caño Limón, Arauca (N $\left.07^{\circ} 05^{\prime} 25^{\prime \prime}-\mathrm{W} 70^{\circ} 45^{\prime} 42^{\prime \prime}\right)$.

Earthworm castings were bought from an E. fetida breeder and compost producer. The worms were grown in a substrate made up of livestock manure, agricultural residue and vegetable residue from country markets.

The selection of the L. sphaericus strains used in this study was based on previous research carried out by the Center of Microbiological Research (CIMIC) at Universidad de los Andes (Bogotá, Colombia) [4]. Microbial bioaugmentation was performed using five strains of L. sphaericus: CBAM5, OT4b.31, OT4b.49, 3(III)7 and 2362. Lab trials have shown great degradation results and survival rates at a concentration of $5 \%$ volume to volume ratio $(v / v)$ of diesel [5]. This consortium is actually used by Biointech in soil remediation processes for the Colombian oil industry resulting in TPH's degradation to permissible levels in periods of time that span from 45 to 60 days under field conditions (Caño Limon, Arauca).

All the containers used for the experiment had holes in the bottom for drainage and were covered with black plastic. The experiment was performed inside a 2 meters $(\mathrm{m})$ wide, $1.2 \mathrm{~m}$ long and $0.8 \mathrm{~m}$ tall light insulated incubator made with white carboard walls on the outside and black plastic in the inside.

\subsection{Composted Soil, Worm Castings and Bacteria Growth}

One month before starting the experiment, a 20 liter $(\mathrm{L})$ plastic container was filled with 2 kilograms $(\mathrm{kg})$ of worm casting mixed with $8 \mathrm{~kg}$ of unpolluted soil collected from the oilfield and $2 \mathrm{~kg}$ of orange peels. The container was covered with black plastic and kept inside a greenhouse. All the worms and amended soil used in this study were extracted from this container that will be referred to as (E0).

L. sphaericus strains' liquid cultures were prepared by growing $1 \times 10^{7}$ Colony-former units (CFU) of each strain in 20 milliliters $(\mathrm{mL})$ of nutrient broth for 24 hours (h) at $30^{\circ} \mathrm{C}$ and 150 revolutions per minute (rpm), resulting in a final concentration of $1 \times 10^{8} \mathrm{CFU} / \mathrm{mL}$.

For the inoculation of soil samples, two trays were filled with $550 \mathrm{~mL}$ of SPC agar each. Using five sterile brushes (one for each strain), the liquid cultures at a concentration of $1 \times 10^{8} \mathrm{CFU} / \mathrm{mL}$ were 
evenly distributed along the surface of the agar occupying 300 square centimeters $\left(\mathrm{cm}^{2}\right)$ per strain in each tray. Both trays were placed in an incubator for $24 \mathrm{~h}$. On the day of inoculation, bacteria that had grown on the surface of the agar were collected using a spatula, resulting in $90 \mathrm{~mL}$ of solution with a concentration of $1 \times 10^{9} \mathrm{CFU} / \mathrm{mL}$ of the consortium.

\subsection{Pretreatment}

Before starting the experiment, a Pretreatment was prepared in order to initiate the biological degradation system before diluting the samples to TPH's concentrations tolerable for earthworms. A Pre-treatment master mix was prepared using a 1:1 weight to weight ratio $(w / w)$ of crude oil sludge and unpolluted soil. Two days later, this mixture was divided into two equal bundles $2.4 \mathrm{~kg}$ each. One of the bundles was mixed with 480 grams (g) of SPC agar without inoculum and the other bundle was mixed with the same amount of agar and $90 \mathrm{~mL}$ of L. sphaericus consortium inoculum at a concentration of $1 \times 10^{9} \mathrm{CFU} / \mathrm{mL}$. Each bundle was divided in half again resulting in four $1.77 \mathrm{~kg}$ bundles that were stored in 20-L plastic containers. Five days later, $30 \mathrm{~g}$ of E. fetida were added to one of the bundles without $L$. sphaericus inoculum and one with inoculum, this bundles corresponded to the final Treatments to be evaluated: E. feitda alone (E), L. sphaericus alone (L), E. fetida with L. sphaericus consortium (EL), and a Control (C) without worms or inoculum, this day was considered as day 0 of the pre-treatment. The pre-treatment was evaluated for a period of 41 days before starting the Treatment.

\subsection{Treatment}

A Treatment master mix was prepared mixing $0.608 \mathrm{~kg}(4.4 \%)$ of crude oil sludge, $14.364 \mathrm{~kg}(53.2 \%)$ of unpolluted soil, and $11.394 \mathrm{~kg}(42.2 \%)$ of worm amended soil from the E0 container, and stored for stabilization for two days inside a $40 \mathrm{~L}$ plastic container covered with black plastic.

On day 0 of the Treatment (day 41 for the Pretreatment), the Treatment master mix was divided into two equal bundles, one of the bundles was inoculated with $90 \mathrm{~mL}$ of consortium at a concentration of $1 \times 10^{9} \mathrm{CFU} / \mathrm{mL}$ and then both bundles were divided again into two equal parts resulting in four $20 \mathrm{~L}$ plastic containers filled with $6750 \mathrm{~g}$ of master mix each, two inoculated with L. sphaericus and two free of inoculum.

After this, E and C pretreatments were diluted to $8.89 \%(w / w)$ each using the two Treatment master mix bundles that were not inoculated, and the same was done for L and EL using the two inoculated bundles. Following this, $250 \mathrm{~g}$ of worms were added to EL and E each resulting in the three final treatments and a control: E. feitda alone (E), L. sphaericus alone (L), E. fetida with L. sphaericus consortium (EL), and (C) without worms or inoculum. At this moment an additional control (CE) composed of $57.7 \%$ unpolluted soil and $42.3 \%$ amended soil with the same quantity of earthworms as Lo and LL was added to the experiment. The amended soil was added to all treatments and controls in order to elucidate the difference between the effects of adding amended soil only and adding the earthworms. The Treatment was evaluated for a period of 52 days.

\subsection{Sampling and Analysis}

During the Treatment temperature and humidity were measured and recorded inside the incubator using an Arduino. TPH's were determined on the Pre-treatments and oil sludge two days prior to the beginning of the Treatment in order to calculate the dilution needed to achieve, at least, a $50 \%$ earthworm survival rate. The $50 \%$ lethal dose was approximated at $20 \mathrm{~g} / \mathrm{kg}$ TPH's based on the toxicity trials made by Martinkosky et al. [11].

DNA was extracted from the earthworms' tissue at the moment of purchase $(\bullet E 0)$. The day previous to the Treatment's master mix preparation, DNA was extracted from crude oil sludge and unpolluted field soil. On day 52, DNA and RNA were extracted from all Treatments including worm tissue $(\bullet \mathrm{E}, \bullet \mathrm{EL}, \bullet \mathrm{CE})$. Ammonium determinations and CFU counts were performed on days $0,9,22,36$ and 52. Ammonium determinations were also performed during the Pretreatment on days 0, 5, 20 and 41 [12]. Samples for ammonium and hydrocarbon determinations and CFU counts were taken 
in triplicate using compound sampling; soil samples for DNA and RNA extractions were taken in triplicate for each treatment and then combined in one compound sample for analysis. For worm samples, $1.5 \mathrm{~g}$ of worms were processed for each Treatment.

\subsection{Ammonium and Hydrocarbon Determination and Microbial Count}

Ammonium concentrations were determined using Merck ammonium test kit catalog no. 114,752. One gram per soil sample was diluted by two orders of magnitude with distilled water prior to analysis. Hydrocarbon determinations were performed using an Oil and Water Retort, $10 \mathrm{~g}$ from each sample was processed following fabricator's recommendations resulting in the separation of a liquid phased composed of oil and water and a solid phase [25]. The liquid phase, contained in the equipment's test tube, was weighed using an analytical balance. Then, the oily fraction from the liquid phase was extracted from the test tube using a pipette and the tube was weighed again, this amount was subtracted from the initial weight of the liquid phase in order to calculate the concentration of the oily fraction. The solid phase was also weighed using an analytical balance, and the volatile fraction was calculated subtracting the solid and total liquid phase from the initial sample weight. The TPH's concentration per kilogram was calculated as the sum of the oily and volatile fractions divided by the sample's initial weight.

CFU counts per gram of sample (CFU/g) were calculated by diluting $1 \mathrm{~g}$ of soil samples to $10^{-4}$, $10^{-5}, 10^{-6}$ with distilled water and inoculating 10 microliter $(\mathrm{uL})$ drops in SPC agar for each dilution in triplicate, final orders of magnitude in each dish were to $10^{-5}, 10^{-6}, 10^{-7}$

Rstudio v 1.1.383 (RStudio Team 2016) software was used for statistical analysis. Differences in ammonium concentrations and UFC counts between treatments were analyzed for each sampling day. The Shapiro-Wilcoxon test was used to evaluate the data for normality. None of the data was distributed normally so the Kruskal-Wallis test was performed to determine significant differences between averages between treatments each day. Statistical analysis results are included in the Supplementary Materials.

\subsection{DNA/RNA Extraction and PCR}

Total DNA was extracted from soil samples and worm tissue using the ZR Soil Microbe DNA MiniPrepTM kit (Catalog No D6001, ZYMO RESEARCH), and the same was conducted for total RNA with the ZR Quick-RNA tissue/insect Miniprep kit (Catalog No R2030, ZYMO RESEARCH). Worm samples were prepared by cleaning the worms' surface by shaking the worms vigorously inside a falcon with distilled water. The water was changed until it maintained its transparency after shaking (around 3 cleaning cycles). Cleaned worms were ground using a mortar and the product was used for DNA/RNA isolation and plate count. DNA extraction from the five L. sphaericus strains was performed by microwaving a colony inside an eppendorf for one minute and then re-suspending the colony in $100 \mathrm{uL}$ of molecular grade water. The eppendorf was then centrifuged for 30 seconds (s) and supernatant containing DNA was transferred to a new eppendorf avoiding the pellet.

Two sets of primers were designed in order to search for the presence and activity of nitrifying bacteria [17]. The first set of primers was designed using L sphaericus genomic annotation where a putative amoA gene is reported [6]. The protein sequence was blasted in order to find conserved regions among $L$ sphaericus populations. Two conserved regions flanking a variable region were selected for primer design resulting in primers amoAputF (5'-GCAGGGTGGATTGCTCAAAAG-3') and amoAputR (5'-GCACAATACTTAAAAAGCCTGTCCT- $3^{\prime}$ ) with an expected PCR product size of 313 base pairs (bp), This primers aligned $100 \%$ with several L. spahericus strains and a Lysinibacillus fusiformis strain's complete genome. For the second set, 38 different amoA sequences from Gram-negative ammonia oxidizing proteobacteria were aligned in order to produce a consensus sequence. Most of the sequence's conserved regions were selected for primer design using NBCI primer blast resulting in primers amoAambF (5'-GGTGACTGGGATTTCTGGCT-3') and amoAambR (5'-GGCCAGTTACCCGGATAGAA-3') with an expected PCR product size of 350 (bp), this primers 
aligned $100 \%$ with more than fifty different ammonia oxidizing proteobacteria uncultured clones. Both primers were used with the same PCR protocol beginning with 3 minutes (min) of denaturation at $94{ }^{\circ} \mathrm{C}$ followed by 35 cycles each with $30 \mathrm{~s}$ of denaturation at $94{ }^{\circ} \mathrm{C}$, annealing at $56^{\circ} \mathrm{C}$ for $30 \mathrm{~s}$ and $1 \mathrm{~min}$ of extension at $72{ }^{\circ} \mathrm{C}$, this protocol ended with $10 \mathrm{~min}$ of extension at $72{ }^{\circ} \mathrm{C}$. Main primer blasts for amoAput and amoAamb are included in the Supplementary Materials.

The primers used to amplify modB were designed by Angelica Cajamarca from the Center of Microbiological Research, Universidad de los Andes based on the genomic annotation conducted by Gómez-Garzón et al. [7] with an expected PCR product size of $312 \mathrm{bp}$. The amplification protocol for this gene started with $3 \mathrm{~min}$ of denaturation at $94{ }^{\circ} \mathrm{C}$ followed by 35 cycles each with $30 \mathrm{~s}$ of denaturation at $94{ }^{\circ} \mathrm{C}$, touchdown annealing from $54{ }^{\circ} \mathrm{C}$ to $51^{\circ} \mathrm{C}$ for $30 \mathrm{~s}$ and $1 \mathrm{~min}$ of extension at $72{ }^{\circ} \mathrm{C}$, this protocol ended with $10 \mathrm{~min}$ of extension at $72{ }^{\circ} \mathrm{C}$.

\section{Results and Discussion}

\subsection{Environmental Conditions and TPH's Concentration}

Temperature and humidity readings showed a temperature oscillation between $28^{\circ} \mathrm{C}$ and $17{ }^{\circ} \mathrm{C}$ and relative humidity between $50 \%$ and $85 \%$ during day, and night, respectively. Temperature and humidity changes during day and night promote earthworm mobilization from the bottom to the surface, thus, increasing substrate homogenization and oxygenation and microbial propagation. Optimal temperature for earthworm development is below the optimal temperature for hydrocarbon degradation by bacterial populations $[4,26]$ but this problem may be solved by the propagation of the bacteria and the migration of earthworms to the bottom of the soil when temperature rise up during the day.

No significant differences were found between samples and the average TPH's concentration was of $112.578 \pm 10.560 \mathrm{~g} / \mathrm{kg}$ for the Pre-treatments and $237.197 \pm 22.528 \mathrm{~g} / \mathrm{kg}$ for crude oil sludge, based on this, initial TPH's concentration in all the Treatments was calculated at $19.593 \pm 1.350 \mathrm{~g} / \mathrm{kg}$. After day 25 of the Pretreatment earthworms begun to die ending in 100\% mortality after one week, this suggest that earthworms are tolerable to high concentrations of heavy crude oil but once degradation starts and more volatile and toxic compounds begin to appear the worms start to die. No significant earthworm mortality was found during the Treatment, meaning that the application of E. fetida can be an efficient strategy for bioremediation and restauration of crude oil contaminated soils, especially during final stages of remediation [11].

\subsection{Bacterial Growth}

Aerobic bacteria cultivation based populations increased significantly in treatments with earthworms (Figure 2), and in the case of $\mathrm{E}$ and $\mathrm{EL}$, bacterial populations were higher as from day $0\left(2.3 \times 10^{7} \mathrm{CFU} / \mathrm{g}\right.$ and $1.03 \times 10^{7} \mathrm{CFU} / \mathrm{g}$ respectively $\left.p=0.02848\right)$ thanks to the colonization that occurred during the pretreatment, while in $\mathrm{CE}$, the presence of earthworms increased bacterial populations constantly from day 22 with an average of $2.65 \times 10^{6} \mathrm{CFU} / \mathrm{g}$ to day 52 with a final count of $1.45 \times 10^{8} \mathrm{CFU} / \mathrm{g}$. The addition of amended soil also increased bacterial populations in treatments without earthworms, $\mathrm{C}$ and L began with $1.96 \times 10^{6} \mathrm{CFU} / \mathrm{g}$ and $2.136 \times 10^{6} \mathrm{CFU} / \mathrm{g}$ on day 0 and reached a maximum of $2.98 \times 10^{7} \mathrm{CFU} / \mathrm{g}$ and $3.3 \times 10^{7} \mathrm{CFU} / \mathrm{g}$ respectively on day 36 . 


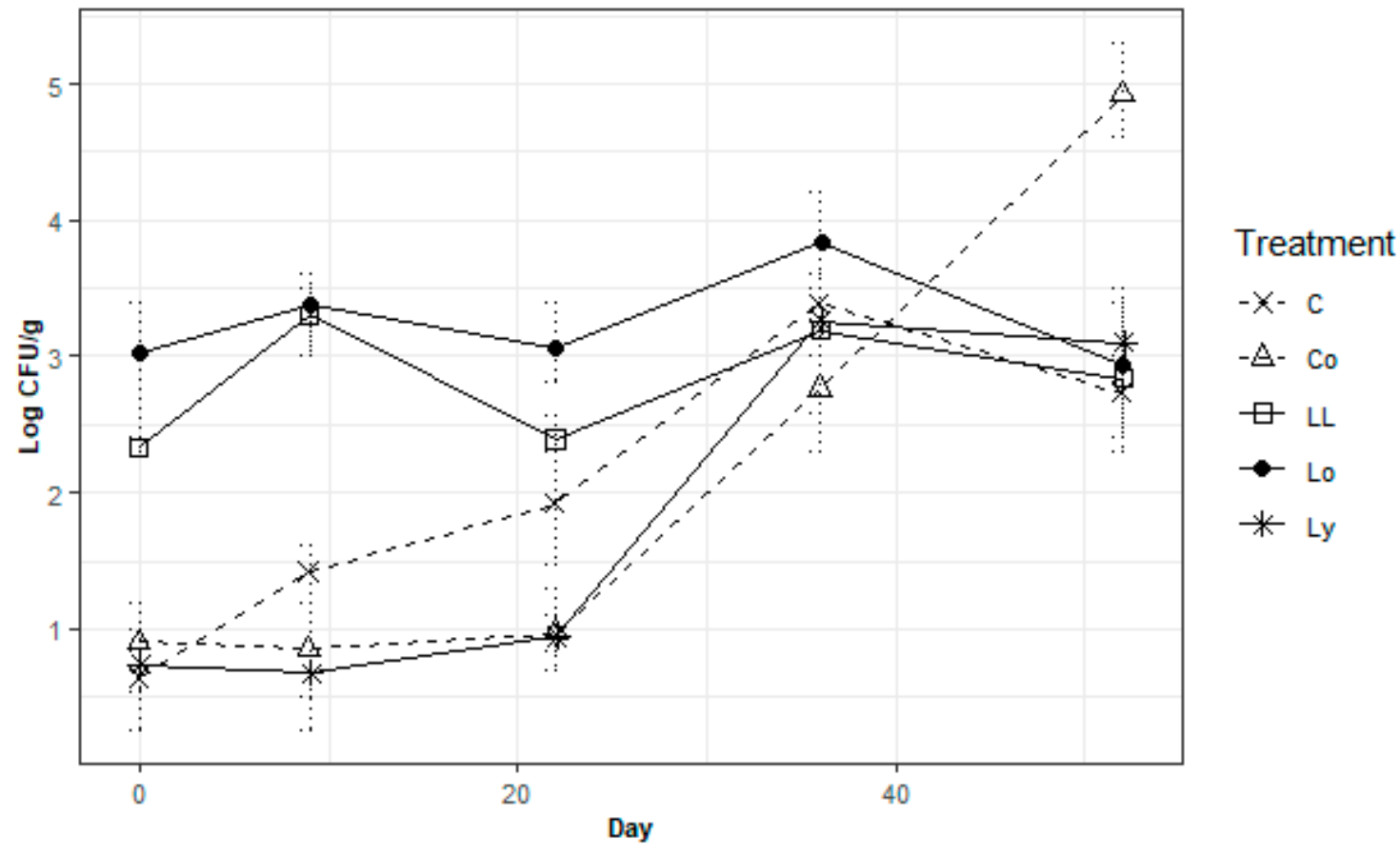

Figure 2. CFU count in soil (Treatment).

All treatments with crude oil seemed to be affected by the appearance of recalcitrant compounds resulting in the reduction of bacterial populations in the last days of the study [23]. Comparing $\mathrm{E}$ with EL, and $C$ with $L$ shows that the presence of $L$. sphaericus affects bacterial populations; this has been evidenced in previous studies where quorum quenching from $L$. sphaericus has been reported in oil sludge remediation [27]. On day 22, this difference was more evident with $2.22 \times 10^{7} \mathrm{CFU} / \mathrm{g}$ and $7.2 \times 10^{6} \mathrm{UFC} / \mathrm{g}$ for E, and C, respectively compared to $1.1 \times 10^{7} \mathrm{CFU} / \mathrm{g}$ and $2.6 \times 10^{6} \mathrm{UFC}$ for EL and $\mathrm{L}$ respectively $(p=0.01308)$.

Soil and worm tissue cultures were analyzed under the microscope (Figure included in Supplementary Materials) revealing that the transit of vegetative cells in the soil through worms' guts promotes their sporulation [28]. These phenomena may improve the recycling of bacterial populations maintaining greater abundance in sludge treated with E. fetida, which could be especially beneficial for L. sphaericus populations, as they tend to decay in oil sludge during the last phases of remediation.

\subsection{Ammonium Concentrations}

During the Pretreatment (Figure 3), the presence of earthworms was related to higher ammonium concentrations on day $41(p=0.02162)$. During the previous sampling days, ammonium concentrations seemed to remain stable between treatments, thus, this sudden differentiation may be related to metabolic inhibition due to high hydrocarbon concentrations. The increment in ammonium concentration during the final days may be evidence of better adaptation capability in degradation systems that include earthworms. 


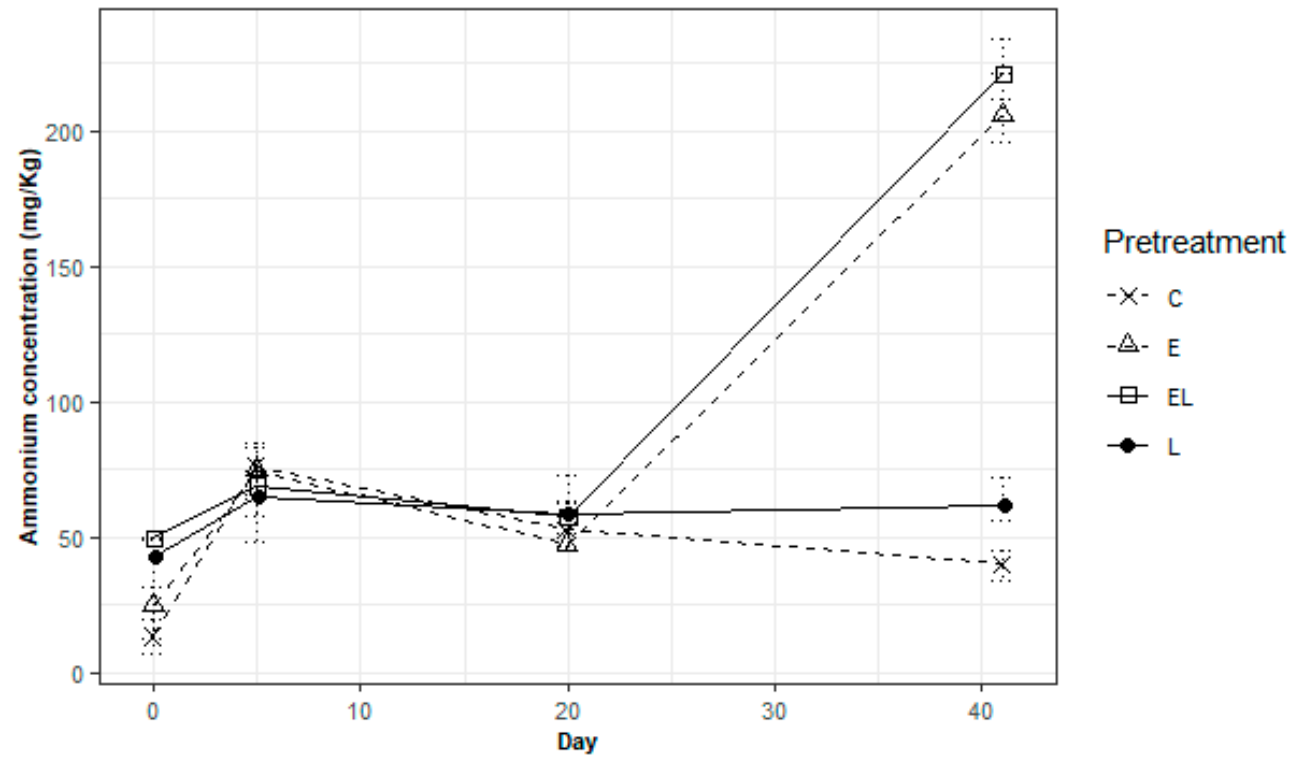

Figure 3. Ammonium concentration in soil (Pretreatment).

Ammonium reached higher concentrations in treatments with E. fetida [29] and L. sphaericus (Figure 4), and differences were greater on day $22(p=0.0218)$ with average ammonium concentrations of C: 26.3 miligrams per kilogram (mg/kgl), L: $75.0 \mathrm{mg} / \mathrm{kgl}$, E: $152.3 \mathrm{mg} / \mathrm{kgl}$, EL: $75.0 \mathrm{mg} / \mathrm{kgl}$ and CE: $64.33 \mathrm{mg} / \mathrm{kgl}$. Earthworms with L. sphaericus inoculum reached only half of the concentration reached by earthworms without inoculum. This could be explained by a higher demand of ammonium for hydrocarbon catabolism by L. sphaericus and/or by ammonium concentrations reaching a threshold producing a transition from fixation to nitrification by L. sphaericus. The latter theory may be supported by the fact that $\mathrm{L}$ reached the same maximum ammonium concentration as EL $(75.0 \mathrm{mg} / \mathrm{kgl}$, day 22). Ammonium concentrations in bioremediation systems tend to behave cyclically thus, such studies can provide evidence to better understand the dynamics between nitrogen fixation and nitrifying bacterial populations and how ammonium and nitrate concentrations regulate this cycle [29].

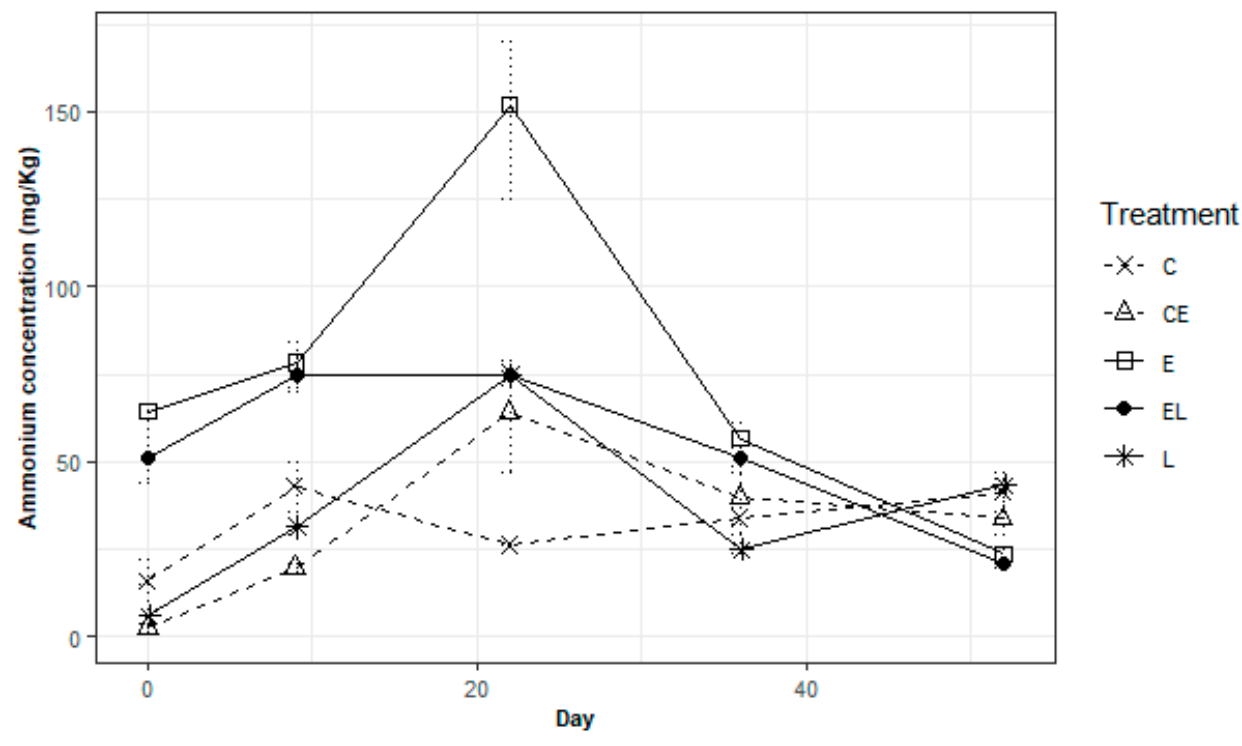

Figure 4. Ammonium concentration in soil (Treatment). 


\subsection{Presence and Expression of AmoA and Molybdenum Transporter Genes}

Putative amoA primers were tested with the five strains of L. sphaericus used in this study. All strains amplified for this set of primers (Figure 5), confirming the genomic annotation calculated by Gómez-Garzón, et al. [6].

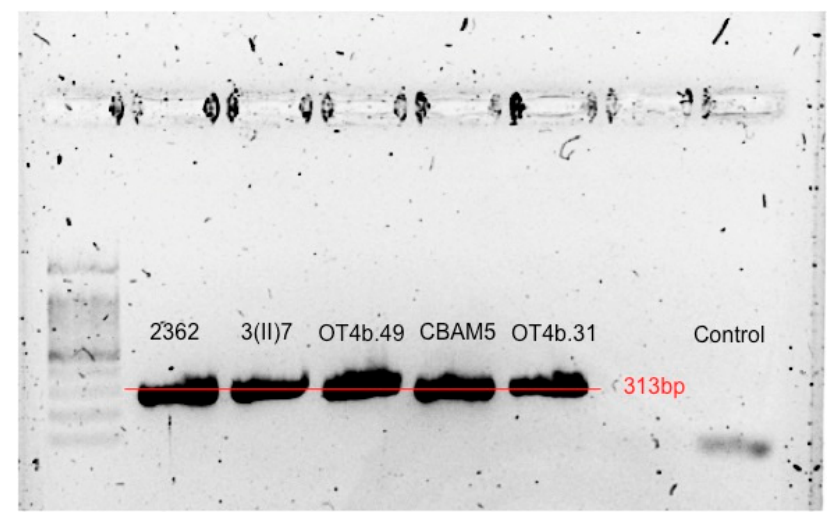

Figure 5. Putative amoA amplification for the L. sphaericus strains used in this study.

No PCR products for amoAamb or amoAput were amplified from the crude oil sludge and the unpolluted field soil indicating that populations of AOB and L. sphaericus were too small or completely absent, and amoAput presence may also go undetected due to L. sphaericus sporulation which impedes cell lysis.

Initial DNA extraction and amplification from earthworm tissue from CE resulted in the presence of both genes indicating that the addition of E. fetida increases AOB populations [14] and that some L. sphaericus strains may be associated with vermicomposting.

PCR of soil and worm DNA and RNA extractions on day 52 for amoAamb and amoAput resulted in positive amplification for all samples (Figure 6). Based on amoAput amplifications from earthworms' tissue in $\mathrm{E}$ and $\mathrm{CE}$, the idea that some strains of L. sphaericus were present previously in the earthworms' tissue is reinforced. The presence of this gene in the soil for all treatments suggests that these bacteria are not only associated to the earthworms' tissue but that E. fetida may increase the populations of these bacteria in soil resulting in the presence of amoAput in the composted soil added to each treatment. Despite nitrate determinations being impossible due to possible rapid assimilation and analytic interference, amoA RNA expression explains reductions in ammonium concentrations in all treatments.

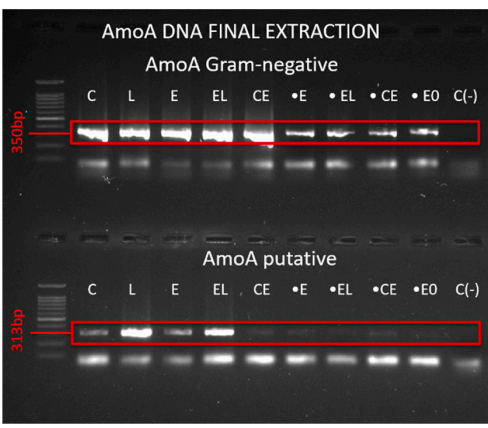

(a)

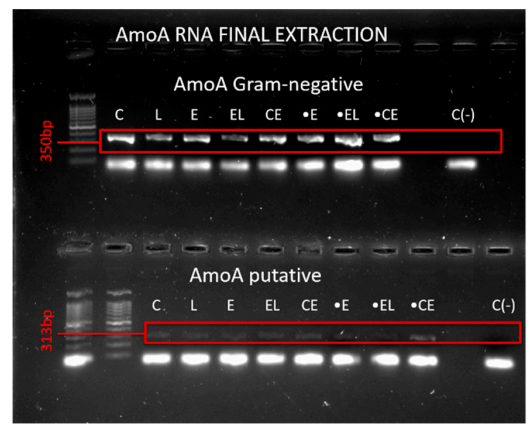

(b)

Figure 6. (a) Electrophoresis gel for Gram-negative and Putative amoA PCR products from final soil and worm tissue DNA extraction; (b) Electrophoresis gel for Gram (-) and Putative amoA PCR products from final soil and worm tissue RNA extraction. 
The expression of amoA RNA in worm tissue was unexpected based on the fact that nitrification is an aerobic process; these results suggest that some regions inside worms' tissue or on the cuticle provide enough oxygen for this process to occur [30].

Soil and worm RNA extractions on day 52 amplified for molybdenum transporter in all samples except for soil RNA from E and EL (Figure 7). The expression of molybdenum transporter may indicate nitrogen fixation by L. sphaericus and this would explain increased ammonium concentrations in all treatments $[7,8]$.

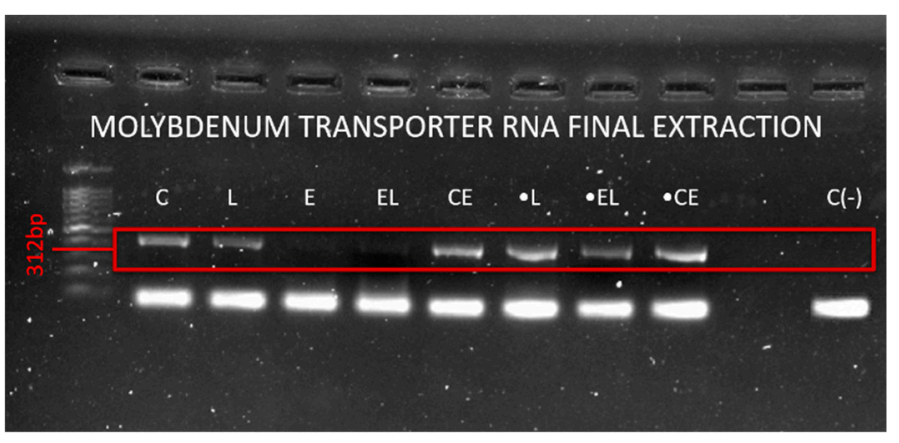

Figure 7. Electrophoresis gel for Molybdenum transporter PCR products from final soil and worm tissue RNA extraction.

The absence of the molybdenum transporter expression in E and EL may be related to theoxygenation of the soil by worm activity. Nitrogen fixation requires low oxygen concentrations; thus, in this case, the process may be inhibited. Nevertheless, expression was found in Co where the effect should be similar for oxygen concentrations, meaning that the inhibition of molybdenum transporter may also be related to compounds derived from hydrocarbon degradation or the nature of fixation-nitrification dynamics. modBexpression was also found in worm tissue from these treatments $(\bullet$ E and $\bullet$ EL) suggesting that worms' guts may provide better conditions for nitrogen fixation [31] when soil contamination causes inhibition.

\section{Conclusions}

The biodegradation processes are highly dependent on bacterial population diversity and dynamics. This study demonstrates the ability of E. fetida to improve the conditions for some of these populations resulting in the promotion of microbial numbers. Ammonia dynamics during the study and amoA genes expression suggests that bacteria associated with E. fetida are involved in nutrient cycling through nitrogen fixation and ammonia nitrification, and this activity is better when the earthworms are present than with worm-amended soil without earthworms. The increment of nitrogen in bioremediation systems may be highly beneficial given the reduction of the $\mathrm{C} / \mathrm{N}$ ratio, which may improve bacterial growth and activity [32]. Increased ammonium concentration may be beneficial for the biodegradation of volatile hydrocarbon compounds given the increased cometabolism by ammonia monooxygenase $[21,23,24]$. The expression of genes related with nitrogen fixation (modB) and ammonium nitrification (amoAput) in oil sludge remediation processes was demonstrated for L. sphaericus, indicating that this species has the ability to degrade hydrocarbons and, at the same time, may improve nitrogen levels in oil sludge bioremediation.

Supplementary Materials: The following are available online at http://www.mdpi.com/2624-7402/2/4/36/s1, Table S1: Pretreatment data, Table S2: Treatment data, Annex S3: Ammonium concentration Pretreatment Statistical Analysis, Annex S4: Ammonium concentration Treatment Statistical Analysis, Annex S5: CFU Treatment Statistical Analysis, Annex S6: Main blast results for amoAamb primers, Annex S7: Main blast results for amoAput primers, Figure S8: Lysinibacillus sphaericus culture from soil and worm tissue samples. 
Author Contributions: Conceptualization, J.D.A. and J.D.; methodology, J.D.A. and J.D.; software, J.D.A.; validation, J.D.A. and J.D.; formal analysis, J.D.A.; investigation, J.D.A; resources, J.D.A. and J.D.; data curation, J.D.A.; writing — original draft preparation, J.D.A.; writing-review and editing, J.D.A. and J.D.; visualization, J.D.A.; supervision, J.D.; project administration, J.D.; funding acquisition, J.D. All authors have read and agreed to the published version of the manuscript.

Funding: This study was funded by the Research Fund INV-2019-84-1827 at the Science Faculty at Universidad de los Andes and the Microbiological Research Center (CIMIC).

Acknowledgments: We are thankful to Biointech for crude oil sludge samples and RETORT analysis.

Conflicts of Interest: The authors declare no conflict of interest.

\section{References}

1. Finer, M.; Jenkins, C.N.; Pimm, S.L.; Keane, B.; Ross, C. Oil and gas projects in the western Amazon: Threats to wilderness, biodiversity, and indigenous peoples. PLoS ONE 2008, 3, e2932. [CrossRef] [PubMed]

2. Ron, E.Z.; Rosenberg, E. Biosurfactants and oil bioremediation. Curr. Opin. iBiotech. 2002, 13, $249-252$. [CrossRef]

3. Wilson, S.C.; Jones, K.C. Bioremediation of soil contaminated with polynuclear aromatic hydrocarbons (PAHs): A review. Environ. Pollut. 1993, 81, 229-249. [CrossRef]

4. Manchola, L.; Dussán, J. Lysinibacillus sphaericus and Geobacillus sp. biodegradation of petroleum hydrocarbons and biosurfactant production. Remediat. J. 2014, 25, 85-100. [CrossRef]

5. Hernández-Santana, A.; Dussán, J. Lysinibacillus sphaericus proved to have potential for the remediation of petroleum hydrocarbons. Soil Sediment Contam. 2018, 27, 538-549.

6. Gómez-Garzón, C.; Hernández-Santana, A.; Dussán, J. A genome-scale metabolic reconstruction of Lysinibacillus sphaericus unveils unexploited biotechnological potentials. PLoS ONE 2017, 12, e0179666. [CrossRef] [PubMed]

7. Martínez, S.A.; Dussán, J. Lysinibacillus sphaericus plant growth promoter bacteria and lead phytoremediation enhancer with Canavalia ensiformis. Environ. Prog. Sustain. Energy 2017, 37, 276-282. [CrossRef]

8. Shabanamol, S.; Divya, K.; George, T.K.; Rishad, K.S.; Sreekumar, T.S.; Jisha, M.S. Characterization and in planta nitrogen fixation of plant growth promoting endophytic diazotrophic Lysinibacillus sphaericus isolated from rice (Oryza sativa). Physiol. Mol. Plant Pathol. 2018, 102, 46-54. [CrossRef]

9. Schaefer, M.; Juliane, F. The influence of earthworms and organic additives on the biodegradation of oil contaminated soil. Appl. Soil Ecol. 2007, 36, 53-62. [CrossRef]

10. Njoku, K.L.; Akinola, M.O.; Anigbogu, C.C. Vermiremediation of soils contaminated with mixture of petroleum products using Eisenia fetida. J. Appl. Sci. Environ. Manag. 2016, 20, 771-779. [CrossRef]

11. Martinkosky, L.; Barkley, J.; Sabadell, G.; Gough, H.; Davidson, S. Earthworms (Eisenia fetida) demonstrate potential for use in soil bioremediation by increasing the degradation rates of heavy crude oil hydrocarbons. Sci. Total Environ. 2017, 580, 734-743. [CrossRef]

12. Contreras-Ramos, S.M.; Alvarez-Bernal, D.; Dendooven, L. Removal of polycyclic aromatic hydrocarbons from soil amended with biosolid or vermicompost in the presence of earthworms (Eisenia fetida). Soil Biol. Biochem. 2008, 40, 1954-1959. [CrossRef]

13. Zhang, B.G.; Li, G.T.; Shen, T.S.; Wang, J.K.; Sun, Z. Changes in microbial biomass C, N, and P and enzyme activities in soil incubated with the earthworms Metaphire guillelmi or Eisenia fetida. Soil Biol. Biochem. 2000, 32, 2055-2062. [CrossRef]

14. Huang, K.; Xia, H.; Cui, G.; Li, F. Effects of earthworms on nitrification and ammonia oxidizers in vermicomposting systems for recycling of fruit and vegetable wastes. Sci. Total Environ. 2017, 578, 337-345. [CrossRef]

15. Singh, A.; Singh, D.P.; Tiwari, R.; Kumar, K.; Singh, R.V.; Singh, S.; Prassana, R.; Saxena, A.K.; Nain, L. Taxonomic and functional annotation of gut bacterial communities of Eisenia foetida and Perionyx excavatus. Microbiol. Res. 2015, 175, 48-56. [CrossRef]

16. Pathma, J.; Sakthivel, N. Microbial diversity ofvermicompost bacteria that exhibit useful agricultural traits and waste management potential. SpringerPlus 2012, 1, 1-19. [CrossRef]

17. Hickman, Z.; Reid, B. Earthworm Assisted Bioremediation of Organic Contaminants. Environ. Int. 2008, 34, 1072-1081. [CrossRef] 
18. Prosser, J.I.; Nicol, G.W. Archaeal and bacterial ammonia-oxidisers in soil: The quest for niche specialisation and differentiation. Trends Microbiol. 2012, 20, 523-531. [CrossRef] [PubMed]

19. Junier, P.; Molina, V.; Dorador, C.; Hadas, O.; Kim, O.S.; Junier, T.; Witzel, K.P.; Imhoff, J.F. Phylogenetic and functional marker genes to study ammonia-oxidizing microorganisms (AOM) in the environment. Appl. Microbiol. Biotechnol. 2010, 85, 425-440. [CrossRef] [PubMed]

20. Fish Health Management Division, Central Institute of Freshwater Aquaculture, Kausalyaganga, Bhubaneswar, India; National Bureau of Fish Genetics Resources, Canal Ring Road, Dilkusha, Lucknow, India. Evaluation and efficacy study of Nitrifying bacteria in freshwater Aquaculture system. Int. J. Curr. Microbiol. App. Sci. 2014, 3, 962-969.

21. Kwapisz, E.; Wszelaka, J.; Marchut, O.; Bielecki, S. The effect of nitrate and ammonium ions on kinetics of diesel oil degradation by Gordonia alkanivorans S7. Int. Biodeterior. Biodegrad. 2008, 61, 214-222. [CrossRef]

22. Rasche, M.E.; Hyman, M.R.; Arp, D.J. Biodegradation of halogenated hydrocarbon fumigants by nitrifying bacteria. Appl. Environ. Microbiol. 1990, 56, 2568-2571. [CrossRef]

23. John, R.C.; Okpokwasili, G.C. Crude oil-degradation and plasmid profile of nitrifying bacteria isolated from oil-impacted mangrove sediment in the Niger Delta of Nigeria. Bull. Environ. Contam. Toxicol. 2012, 88, 1020-1026. [CrossRef]

24. García-Rivero, M.; Peralta-Pérez, M.R. Cometabolism in de Biodegradation of Hydrocarbons. Rev. Mex. Ing. Quim. 2008, 7, 1-12.

25. Fann Instrument Company. Oil and Water Retort Instruction Manual; Fann Instrument Company: Houston TX, USA, 2019; pp. 4-6.

26. Presley, M.L.; McElroy, T.C.; Diehl, W.J. Soil moisture and temperature interact to affect growth, survivorship, fecundity, and fitness in the earthworm Eisenia fetida. Comp. Biochem. Physiol. 1996, 114, 319-326. [CrossRef]

27. Gómez-Garzón, C.; Dussán, J. Evidence-based validation of quorum quenching from Lysinibacillus sphaericus and Geobacillus sp. in bioremediation of oil sludge. Can. J. Microbiol. 2016, 63, 74-82. [CrossRef]

28. Schuch, R.; Pelzek, A.J.; Kan, S.; Fischetti, V.A. Prevalence of Bacillus anthracis-like organisms and bacteriophages in the intestinal tract of the earthworm Eisenia fetida. Appl. Environ. Microbiol. 2010, 76, 2286-2294. [CrossRef]

29. Burns, R.C.; Hardy, R.W. Nitrogenase: The Catalyst. In Nitrogen Fixation in Bacteria and Higher Plants, 1st ed.; Springer Science \& Business Media: Berlin/Heidelberg, Germany, 1975; Volume 21, pp. 74-105.

30. Ihssen, J.; Horn, M.A.; Matthies, C.; Gößner, A.; Schramm, A.; Drake, H.L. N2O-producing microorganisms in the gut of the earthworm Aporrectodea caliginosa are indicative of ingested soil bacteria. Appl. Environ. Microbiol. 2003, 69, 1655-1661. [CrossRef]

31. Wertz, J.T.; Kim, E.; Breznak, J.A.; Schmidt, T.M.; Rodrigues, J.L. Genomic and physiological characterization of the Verrucomicrobia isolate Diplosphaera colitermitum gen. nov., sp. nov., reveals microaerophily and nitrogen fixation genes. Appl. Environ. Microbiol. 2012, 78, 1544-1555. [CrossRef] [PubMed]

32. Goldman, J.C.; Caron, D.A.; Dennett, M.R. Regulation of gross growth efficiency and ammonium regeneration in bacteria by substrate C: $\mathrm{N}$ ratio. Limnol. Oceanogr. 1987, 32, 1239-1252. [CrossRef]

Publisher's Note: MDPI stays neutral with regard to jurisdictional claims in published maps and institutional affiliations.

(C) 2020 by the authors. Licensee MDPI, Basel, Switzerland. This article is an open access article distributed under the terms and conditions of the Creative Commons Attribution (CC BY) license (http://creativecommons.org/licenses/by/4.0/). 